\title{
IMPROVEMENT OF MEDIA COMPETENCE WITHIN COOPERATIVE LEARNING PROCESS IN A VOCATIONAL EDUCATION INSTITUTION
}

\author{
Tamara Pigozne \\ University of Latvia, Latvia \\ Aivars Pigoznis \\ Rezekne Art and Design Secondary School, Latvia
}

\begin{abstract}
Basing on the theoretical formulations concerning the functions and competence of media, as well as cooperative learning the authors developed a model aimed at improvement of media competence of the vocational education institutions' students. The elaborated model offers teachers in various vocational educational institutions to generate and develop ideas for media competence perfection, ensuring an opportunity in an interdisciplinary project to use the multiform functions of media competence (information, technologies, computer, network, critical and visual) and cooperative learning to ensure efficient learning process. The aim of the article is to analyze the results obtained during the approbation of the model for improvement of the media competence within the cooperative learning process in a vocational education institution.
\end{abstract}

Keywords: media, media competence, cooperative learning.

\section{Introduction}

In the $21^{\text {st }}$ century in Latvia the content of educational programs related to design, standards of the subjects and programs are being updated, the accents switch from learning to learning in choice of teaching methods; in addition the need in cooperation with the Ministry of Education and Science, Ministry of Culture, representatives of state institutions and non-governmental organisations, employers, social partners, teachers, parents and students is emphasized in order to connect the theory and practice, and inter-subject relation corresponding to the demand of labour market, specificity of region and school, requirements of external and internal normative acts, resources, the level of students' knowledge, their skills, abilities and individualities.

The topicality of the article lies in the requirement the education faces as a result of the changes happening in the society, namely, to develop competence, which would help a person to implement him/herself in the changing society, to integrate in the labour market and improve own life quality. In the epoch of postmodernism, when access has become a lifestyle, media competence is mentioned as an uppermost resource in achieving the mentioned goals. So far analysis of media competence mostly concerns mass media. The novelty of the work lies in a broader view of media as a pedagogical tool with didactic or 
educational aim and opportunities to improve media competence from the pedagogical aspect.

\section{Theoretical Framework}

A medium is a sign of culture or art, representing the meanings (Plaude, 2003; Маклюэн, 2003).

The research updates and emphasizes the informative, communicative, creative, integrating, educational and instructional function of media (Куриллова, 2005; Rubene et al., 2008), as well as the classification of media is significant, choosing as a criterion specific character of a certain field:

- in communication science a medium is a sign or symbol representing the meaning of the message;

- within a learning process a medium is viewed as a teaching tool having a didactic or educational purpose.

Furthermore, according to this classification also a show-window, as a teaching tool having a didactic or educational purpose within a learning process, may be the learning and teaching, as well as both closed and opened medium, and a medium that promotes perception, imagination and thinking (Zimmer, 2005).

The authors of the article ground on the media competence definition (Tyner, 1998), proposing it as a skill to access, analyze, evaluate and spread information in broad variety of forms aimed at facilitation of artistic selfexpression, facilitating the a long-term development of a school, protection of youth from the harmful influence, fighting with strengthening the industry of media and fortifying citizenship.

There is still no unified understanding about media competence classification. Corresponding to the theoretical formulations the research deals with analysis of the following kinds of media competence: information, technologies, computer, network competence, critical and visual (McClure, 1994; Allemann-Ghionda, 2004; Andrews, 2004; Rubene et al., 2008; Hippel, 2010; Ferrés, \& Piscitelli, 2012).

Social constructivism approach (Vygotskij, 1978) accentuates the environment of students and environment, influencing the increase in use proportion of such educational approaches as cooperative learning, experimentation, project work.

Cooperative learning is defined as "a form of teaching and learning, focused on the social interaction of students" (Huber et al., 1984:13), joined activity, in the centre of which is students' activity (Drebes, 1993), aimed at advancing the involvement of students in learning process (Plaude, 2004), providing them opportunities to participate in work planning and making decisions, exchanging the ideas and suggestions (Hertz-Lazarowitz \& Shachar, 1990; Šahara \& Šarans, 2004), where ,work productivity increases in proportion 
to the degree of cooperation, since exchange is the precondition of problem solution" (Koena, 2004:56).

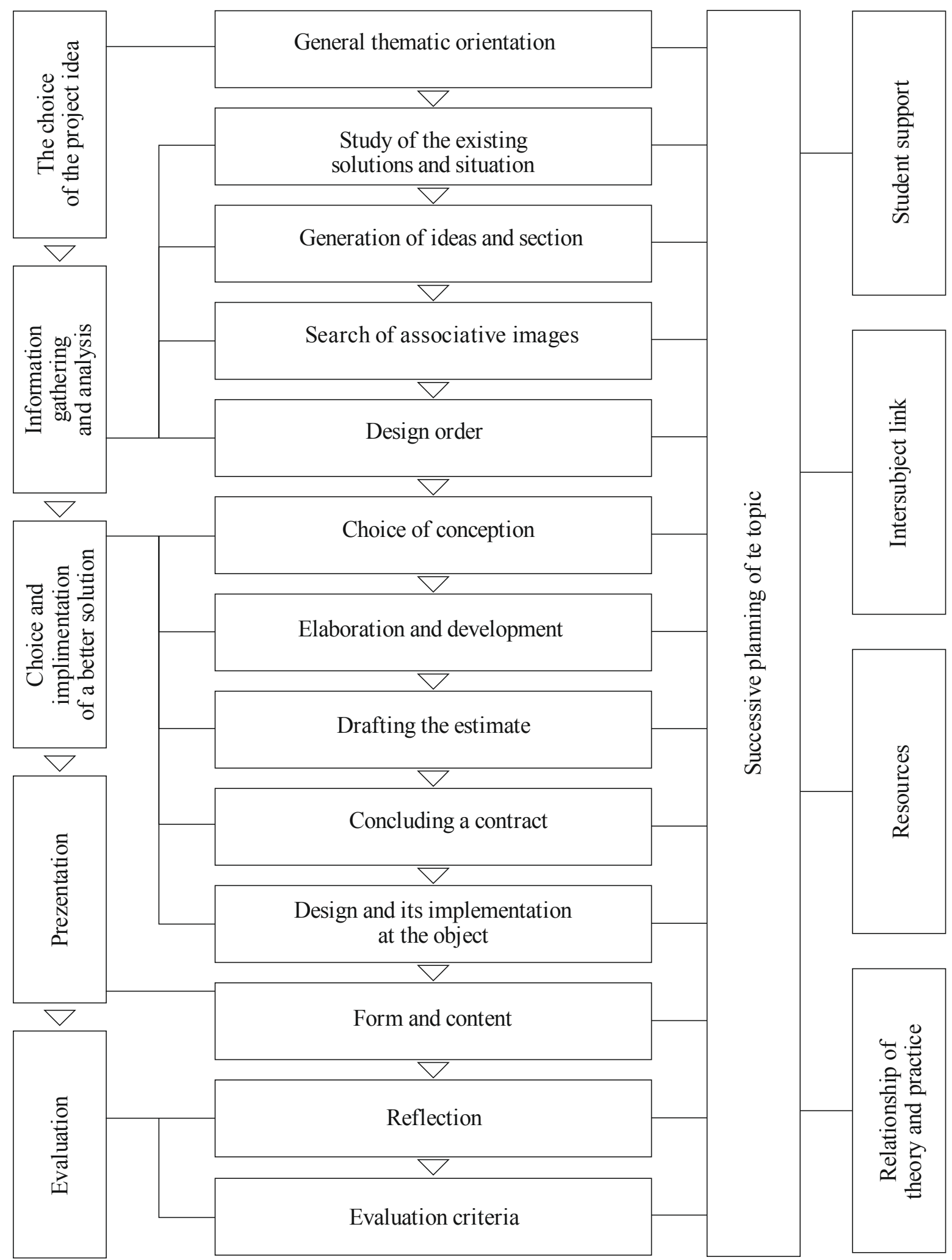

Figure 1. Model for Improvement of Media Competence in Cooperative Learning in a Vocational Learning Establishment 
During the first years of studies in the framework of educational program "Environmental Design", in the subject called "Craft Studies", first of all, students get to know the materials, the tools applicable in decorative works, techniques of spatial environment mapping; furthermore, they obtain knowledge about the qualities and compatibility of various materials applicable in practice, work skills in application of various materials in complex activity. The subject "Craft Studies" ensures an intersubject link with the subjects of general education, for instance, "Mathematics", by performing calculation, drafting an estimate, and other specialized subjects, such as, "Composition", "Computer Graphics" etc. The students have already obtained the understanding about a composition, the unity of a form and content, such composition's means of expression as a line, area, tonality, texture, finish, relationship of an element and area, object and background, optical deformation of a plane, principles of formation of natural forms stylization, diversity of natural elements, ink colours and their accordance; in addition, they have the knowledge about chromatics, relationship of background and accent, font and area, colour relationship of spatial environment, spatial thinking, about performing study and analysis of forms, rules of forming visual information elements, tendencies of styling, application of elements in creating a spatial image; ability to use the qualities of materials in solution of a formal composition, to observe the rules of solving three-dimensional compositions, to use various kinds of project presentations. The fourth year of studies provides 36 lessons for the subject, emphasizing the relation of theory and practice, practical application of knowledge and abilities in the environment, implementation of ideas using materials keeping in mind a thought to create high-quality works through the environmental design, allowing to implement in practice the project called "Show-Window Design" (see Table 1).

The structure of the model embodies project stages, successive planning of the topic, inter-subject link, relationship of theory and practice, resources, student support (see Figure 1).

\section{Methodological Framework}

The present research deals with 38 students of the education program "Environmental Design" in the Rezekne Arts and Design Secondary School, who participated in the study. On the basis of theoretical formulations the authors elaborated a system of criteria and indicators (see Table 2). The data obtained in the survey were processed in the environment of SPSS program for processing quantitative data, using the descriptive statistics (arithmetic mean), Wilcoxon test (Wilcoxon Signed ranks test, Two related samples test) and Kendall's correlation analysis (Kendall's tau-b). 
Table 1. Content of the Model for Improvement of Media Competence within Cooperative Learning in a Vocational Learning Establishment

\begin{tabular}{|c|c|c|}
\hline No. & steps & content \\
\hline 1. & $\begin{array}{l}\text { The choice of } \\
\text { the project } \\
\text { idea }\end{array}$ & general thematic orientation \\
\hline 2. & \multicolumn{2}{|c|}{ Gathering information and its analysis } \\
\hline 2.1. & $\begin{array}{l}\text { Study of the } \\
\text { existing } \\
\text { solutions and } \\
\text { current } \\
\text { situation }\end{array}$ & $\begin{array}{l}\text { review of illustrative material - photomaterial, internet resources, } \\
\text { urban environment resources; constructive solutions; applicable } \\
\text { materials; measurement of facades and show-windows; scale drawing } \\
\text { of a facade; photo fixation of environment }\end{array}$ \\
\hline 2.2. & $\begin{array}{l}\text { Generation } \\
\text { and selection } \\
\text { of ideas }\end{array}$ & listing wordy associative images, processes \\
\hline 2.3 . & $\begin{array}{l}\text { Search of } \\
\text { associative } \\
\text { images }\end{array}$ & $\begin{array}{l}\text { image visualization; variations; formation of an environment; } \\
\text { compositional arrangement of elements; inter-elemental proportions } \\
\text { (scale modelling, demonstration system, provisional scheme of light } \\
\text { distribution); coloristic solutions; provisional calculation of costs, } \\
\text { drafting an estimate project; exploration of the applicable } \\
\text { technologies; exploration and choice of the materiāls }\end{array}$ \\
\hline 2.4. & Design order & $\begin{array}{l}\text { defining work tasks; time planning; meeting entrepreneurs to agree on } \\
\text { a specific working object, coordinate a work schedule and volume, } \\
\text { confirm the sketches; exploitation requirements; aesthetical } \\
\text { requirements; compositional unity with existing elements, inter- } \\
\text { elemental proportions, unity of the image }\end{array}$ \\
\hline 3. & \multicolumn{2}{|c|}{ Choice and implementation of a better solution } \\
\hline 3.1. & $\begin{array}{l}\text { Choice of } \\
\text { conception }\end{array}$ & $\begin{array}{l}\text { assessment of an idea (visual effect, correspondence to the concept, } \\
\text { originality, materials, technologies, time, costs); choice of the idea; } \\
\text { confirmation of idea }\end{array}$ \\
\hline 3.2. & $\begin{array}{l}\text { Elaboration } \\
\text { and } \\
\text { development }\end{array}$ & $\begin{array}{l}\text { detailed elaboration of the image and environment; digitalized } \\
\text { elaboration of elements; formation of a prototype (fragment); } \\
\text { development of lighting scheme }\end{array}$ \\
\hline 3.3. & $\begin{array}{l}\text { Drafting the } \\
\text { estimate }\end{array}$ & $\begin{array}{l}\text { planning the sequence of work processes; precise exploration of costs } \\
\text { (materials, facilities, technological services, transport); confirmation of } \\
\text { the estimate; coordination of the idea and costs with the commissioner }\end{array}$ \\
\hline 3.4. & \multicolumn{2}{|c|}{ Concluding a contract } \\
\hline 3.5 . & \multicolumn{2}{|c|}{ Design and its implementation at an object } \\
\hline
\end{tabular}


SOCIETY. INTEGRATION. EDUCATION. Volume II

\begin{tabular}{|l|l|l|}
\hline 4. & Presentation & unity of content and form; performing in front of an audience \\
\hline 5. & Evaluation & \\
\hline 5.1. & $\begin{array}{l}\text { Reflection on } \\
\text { the work }\end{array}$ & $\begin{array}{l}\text { What was the aim and task of the project? } \\
\text { Have they been achieved? } \\
\text { What has been done the best within the project? What was not so } \\
\text { successful? Why? What would you do differently? } \\
\text { What is the influence of your project - what people did you manage to } \\
\text { involve, what was made, what could happen to the final result of the } \\
\text { project next? } \\
\text { What was the feeling during the project implementation like? } \\
\text { Did your understanding, opinion about things and events changed } \\
\text { during the project? } \\
\text { What did you learn? How will you be able to use it? } \\
\text { What materials are provided for the work? Why? } \\
\text { How do you plan to join the parts? } \\
\text { How suitable was the chosen material? } \\
\text { What would you suggest the ones who planned a similar project? }\end{array}$ \\
\hline 5.2. & $\begin{array}{l}\text { Evaluation } \\
\text { criteria }\end{array}$ & \begin{tabular}{l} 
the constructive solution; quality of performance; rational use of time \\
\hline
\end{tabular} \\
\hline
\end{tabular}

\section{Findings and Discussion}

During the stage No.1 applying the descriptive statistics, the authors calculated the arithmetic mean of media competence criteria (its functions). The results show that computer competence has the highest indicator $(\mu=4.13)$, and visual competence - the lowest $(\mu=3.42)$. Probably it is because youth has good computer skills; they have acquired them very early, however, the specificity of the school determines that a greater attention is paid to the visual competence and it has higher requirements.

The results of indicators of information competence prove that the students appreciate higher the ability to be conscious of the need in information, find, evaluate, use it, and they appreciate lower the ability to analyse and synthesize the necessary information and ability to be conscious of the ethical, legal, social and political aspects of information and technologies. Probably it proves that students are aware of the significance of information in the modern informative society, but the ability of analysis and synthesis is related to rather complicated thinking operations, which require training and experience. Likewise, the state of being conscious of legal, social and political aspects require knowledge, experience and a certain degree of maturity, however young people often have not developed them well enough at their age. Value-orientations determine the awareness of ethical aspects, whereas the value system of a young person is not steady yet. In the modern informative space there is a very fragile border between the good and the bad, the beautiful and the ugly, the villainous and the 
sublime - young people often have difficulties to be competent in the wide range of offers and they get confused.

The acquired indicators of technologies competence prove that the students consider the skill of using and applying multiform technologies, analysing their advantages and disadvantages to be more important. It is natural that youth has very good knowledge about technologies. The level of other criteria is lower, since the ability to make conscious choices among the technology systems, analyze their advantages and disadvantages is related to responsibility and intellectual work, what is not typical of many adolescents at this age.

The level of all indicators of computer competence is optimal, and for 1 student - it is high. Although this generation of adolescents generally has no difficulties in using computers, there is also a potential opportunity to improve this ability. Perhaps many teenagers are conscious of the wide range of possibilities and also risks that are behind a computer.

Concerning the network competence evaluation, according to the opinion of the surveyed students, they are competent in hypertext structures and internet resources, as well as they use the internet at an optimal level; they believe that the skill to access and create resources, to communicate with other people is less important. Young people face greater difficulties to create resources, since it requires daring, initiative and knowledge. Due to the specific character of the school, the students have a bigger proportion of individual work; they spend a lot of time alone - performing modelling, creating and forming various things. However, a subject called "Communication" to a great extent compensates the lack of communication.

Naturally, the students of Art and Design Secondary School, when evaluating critical competence, assess their abilities to understand and use visual images, think and learn in terms of images - think visually - at a higher level. They evaluate their skill to create images in the diversity of media, visual aids in various mobile and static forms of media and awareness of culture and knowledge about texts of images, ability to form and model them lower. Probably the students do not use their potential in creation of visual aids sufficiently, as well as possibly the students have superficial knowledge of image texts, because they read very little. Critical competence is based on critical thinking, mostly influenced by wide horizon and erudition.

The students believe that their self-control, self-correction, also critical using of network, awareness of ethical issues related to visual competence as users of media is at optimum level. Supposedly it is the result of students' and teachers' cooperation. However, many of the young people have analytical thinking, reading and writing habits, comprehension about social context and consequences, understanding the deepest point of an event, text, technique, process, object, statement, image or situation of a topic at an average level. 
It is very well, that none of the students believes that his/her media competence is at a low or critical level, but at the same time they are aware of their potential opportunities to improve it.

Table 2. System of Criteria and Indicators of Media Competence

\begin{tabular}{|c|c|}
\hline criteria & indicators \\
\hline \multirow{4}{*}{$\begin{array}{l}\text { Information } \\
\text { competence }\end{array}$} & skill to be aware of the need in information, to find, evaluate and use it \\
\hline & skill to analyse and synthesize the necessary information \\
\hline & skill to share the information with others, create new knowledge \\
\hline & $\begin{array}{l}\text { skill to be aware of ethical, legal, social and political aspects of information } \\
\text { and technologies }\end{array}$ \\
\hline \multirow[t]{3}{*}{$\begin{array}{l}\text { Technologies } \\
\text { competence }\end{array}$} & $\begin{array}{l}\text { skill to use and apply multiform technologies, analyse their advantages and } \\
\text { disadvantages }\end{array}$ \\
\hline & $\begin{array}{l}\text { skill to make conscious choices among systems, resources and services of } \\
\text { technologies }\end{array}$ \\
\hline & $\begin{array}{l}\text { skill to cooperate, using technologies, gathering data, synthesizing, selecting } \\
\text { and distributing information and doing other creative works }\end{array}$ \\
\hline \multirow[t]{3}{*}{$\begin{array}{l}\text { Computer } \\
\text { competence }\end{array}$} & $\begin{array}{l}\text { understanding the principles of computer's work and it's kinds, } \\
\text { opportunities to use it as a resource }\end{array}$ \\
\hline & $\begin{array}{l}\text { skill to use computer, use the opportunities provided by a computer in the } \\
\text { own branch of activity }\end{array}$ \\
\hline & $\begin{array}{l}\text { understanding of ethic, cultural and social issues in relation to computer } \\
\text { technologies }\end{array}$ \\
\hline \multirow[t]{3}{*}{$\begin{array}{l}\text { Network } \\
\text { competence }\end{array}$} & $\begin{array}{l}\text { skill to be competent in hypertext structures and internet resources, as well } \\
\text { as internet using }\end{array}$ \\
\hline & $\begin{array}{l}\text { skill to manipulate with the network information, combining it with other } \\
\text { resources, improving it or otherwise raising the value of information for } \\
\text { particular situations }\end{array}$ \\
\hline & skill to access and create resources, to communicate with other people \\
\hline \multirow[t]{3}{*}{$\begin{array}{l}\text { Critical } \\
\text { competence }\end{array}$} & $\begin{array}{l}\text { skill to be competent in literary texts, use films, video, computers and } \\
\text { internet not only to establish facts, but also for text analysis and } \\
\text { interpretation }\end{array}$ \\
\hline & $\begin{array}{l}\text { self-control, self-correction oneself as a user of media, also critical using of } \\
\text { network, awareness of ethical issues }\end{array}$ \\
\hline & $\begin{array}{l}\text { analytical thinking, reading, writing or discussion habits, comprehension } \\
\text { about social context and consequences, understanding the deepest meaning } \\
\text { of every event, text, technique, process, object, statement, image or situation } \\
\text { of a topic }\end{array}$ \\
\hline \multirow[t]{3}{*}{$\begin{array}{l}\text { Visual } \\
\text { competence }\end{array}$} & $\begin{array}{l}\text { skill to understand and use visual images, think and learn in terms of } \\
\text { images - to think visually }\end{array}$ \\
\hline & $\begin{array}{l}\text { to create images in the diversity of media, visual aids in various moving and } \\
\text { static forms of media }\end{array}$ \\
\hline & $\begin{array}{l}\text { awareness of culture and knowledge about texts of images, ability to form } \\
\text { and model them }\end{array}$ \\
\hline
\end{tabular}


As the empirical distribution of the research variables did not comply with the normal distribution, during the research stage No.2 the authors applied the descriptive statistics (the arithmetic mean) and methods of nonparametric statistics - Wilcoxon test (Wilcoxon Signed ranks test, Two related samples test) to establish the differences between the results of the first and the second measurements for 2 dependent selections and Spearman correlation analysis to determine connections.

To determine the dynamics of media competence, the authors calculated the arithmetic mean for each criterion and indicator (see Figure 2). The results of the descriptive statistics (arithmetic mean) show a positive dynamics of information, technology, computers, network, critical and visual competence indicators. They prove that pedagogical intervention in the process of teaching the topic "Show-window design" has been successful.

The results of Wilcoxon test reflect the dynamics of media competence criteria (functions) and indicate that it is positive or unchanged. Much greater is the proportion of the cases with a positive dynamics, in comparison with the number of cases where it remains the same. There were established no cases with negative dynamics. It indicates that during the process of teaching the topic "Show-Window Design" all the media competence functions were activated.

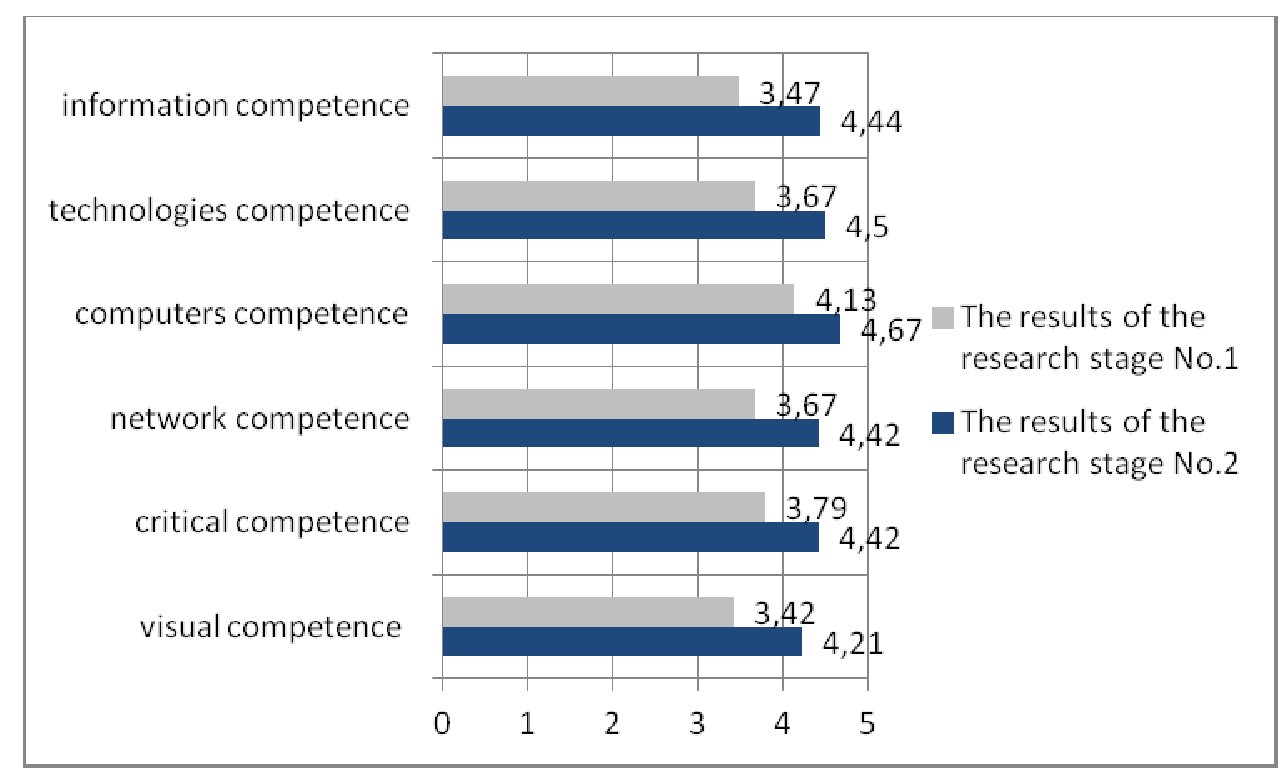

Figure 2. The Dynamics of Media competence

The results of Wilcoxon test (Wilcoxon Signed ranks test, Two related samples test) show a crucial and important differences between the indicators of information competence:

- the ability to be aware of the need in information, to find, evaluate, use it; ability to share information with others, create new knowledge and ability to be conscious of the ethical, legal, social and political 
aspects of information and technologies of all (8) students improved $(\mathrm{p}=0,005)$;

- $\quad$ ability to analyse and synthesize necessary information of 5 students has improved, of 3 students has remained at the former level $(\mathrm{p}=0,038)$.

The information competence improved during the process of teaching and learning the topic "Show-Window Design", using skills of research work, summarizing, grouping and analysing information on the windows of the town.

There are statistically crucial and significant differences between the indicators of technology competence:

- $\quad$ ability to use and apply various technologies, analyze their advantages and disadvantages of 7 students has improved, of 1 student it has remained at the former level $(\mathrm{p}=0,008)$;

- ability to make informed choices among the technologies of systems, resources and services of 8 students has improved $(p=0,005)$;

- the ability to cooperate with peers, experts and others, using technologies, gathering data, synthesizing, selecting and distributing information, models and other creative works, of 5 students has improved, of 3 students has remained at the former level $(p=0,025)$.

There are statistically significant differences between the indicators of computer competence:

- comprehension on a computer's working principles, it's use computer as a resource of 4 students has improved, of 4 students it has remained at the former level $(\mathrm{p}=0,046)$;

- comprehension of ethical, culture and social issues in relation to computer technologies of 6 students has improved, of 2 students it has remained at the former level $(p=0,014)$.

There are statistically crucial differences $(p=0,014)$ between the indicators of network competence: ability to be competent in hypertext structures and internet resources, as well as internet using; ability to manipulate with the network information, combine it with other resources, improving it or otherwise raising the value of information for special situations and the skill to access and create resources, to communicate with other people of 6 students have improved, of 2 students they have remained at the former level.

There are statistically significant differences between the indicators of critical competence:

- $\quad$ ability to be competent in literary texts, use films, video, computers and internet not only to establish facts, but also for text analysis and interpretation of 5 students has improved, of 3 students has remained at the former level $(\mathrm{p}=0,025)$; 
- the self-control, self-correction oneself as a user of media, also critical using of network, awareness of ethical issues of 4 students has improved, of 4 students has remained at the former level $(p=0,046)$;

- analytical thinking, reading, writing or discussion habits, comprehension about social context and consequences of every topic, understanding the deepest meaning of every event, text, technique, process, object, statement, image or situation of 6 students has improved, of 2 students has remained at the former level $(p=0,014)$.

There are statistically significant differences between the indicators of visual competence:

- $\quad$ ability to use visual images, think and learn in terms of images - to think visually of 7 students has improved, of 1 student has remained at the former level $(\mathrm{p}=0,008)$;

- $\quad$ ability to create images in the diversity of media, visual aids in various moving and static forms of media and awareness of culture and knowledge about texts of images, ability to form and model them of 7 students has improved, of 1 student it has remained at the former level $(\mathrm{p}=0,014)$.
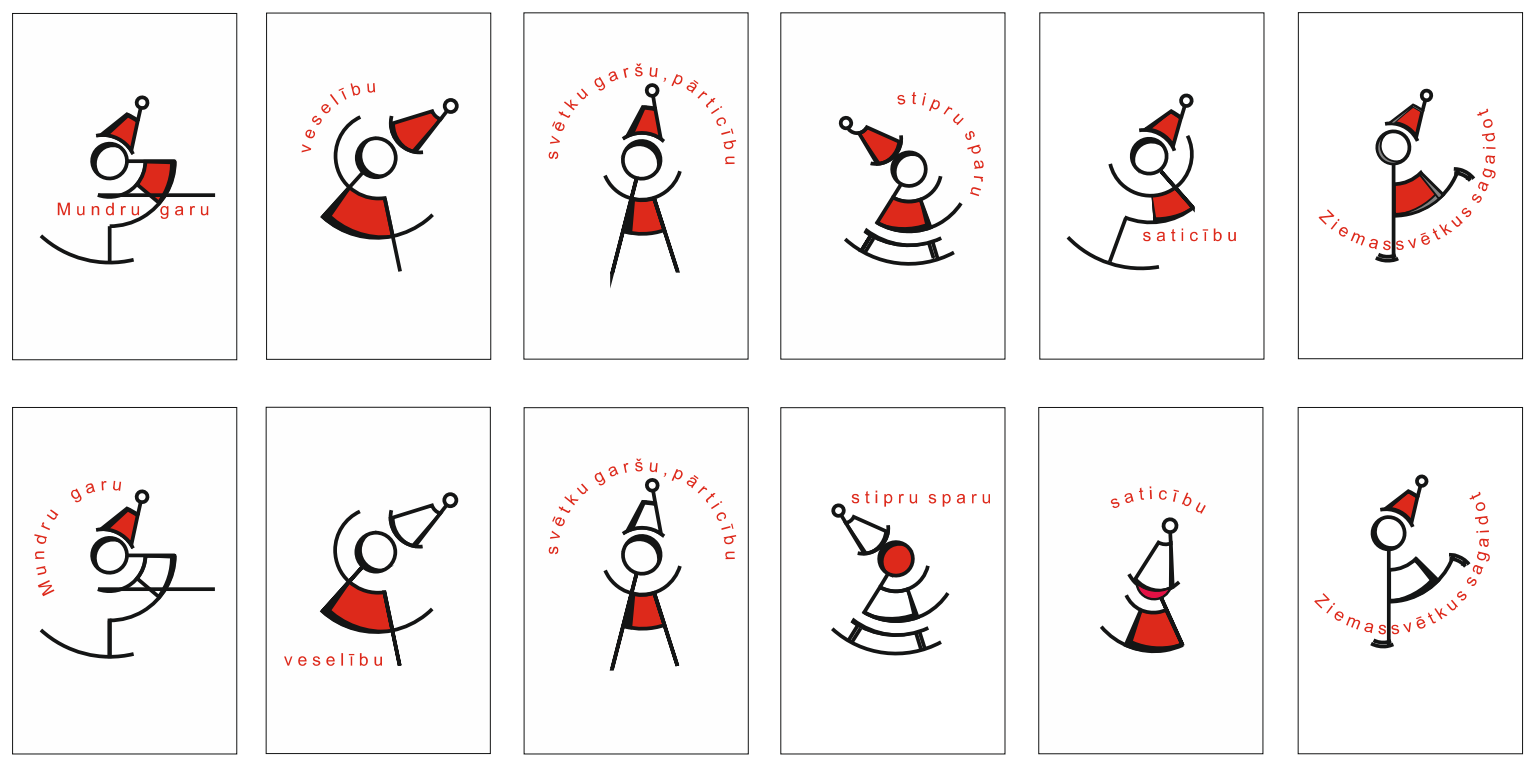

Figure 3. Christmas and New Year window decorations of the stores: Sketches created by the students of study programme on environment design (I)

To find out the correlation between the media competence criteria, the authors used Spearman correlation analysis. During the first measurement there was no statistically significant correlation among criteria, but it was established among the indicators. In 2 cases there were statistically crucial differences between the skill to orient oneself in literary texts, use films, video, computers and internet not only to establish facts, but also for text analysis and interpretation, and ability to comprehend and use visual images, think and learn 
in terms of images - to think visually $(r=1,000 ; p=0,000)$, as well as the ability to create images in the diversity of media, visual aids in various mobile and static forms of media and awareness of culture and knowledge about image texts, ability to form and model them $(\mathrm{r}=1,000 ; \mathrm{p}=0,000)$. During the second measurement there was statistically crucial differences between the comprehension on computer working principles, kinds and opportunities of it's use as a resource and abilities to manipulate with the network information, combine it with other resources, improving it or otherwise raising the value of information for special situations $(r=-1,000 ; p=0,000)$. It proves that knowledge does not guarantee and does not ensure their use, whereas students are able to use computer skilfully, manipulate and combine it with other resources.

However, within the elaboration of the project, using the cooperative learning, students have an opportunity to apply the acquired theoretical knowledge in practice and use them in real situations.

Object measurement provides precise information on the spatial dimensions of design (exposition), teaches a methodical approach in performing works, accuracy in measurements and notes, since any inaccuracy may require additional costs. Scanning a facade outlines a precise area for compositional solutions. Modelling makes the visual perception of festive design easier, completes the notion of the design (arrangement of spatial composition elements in a specific show-window and general impression of the exposition).

Furthermore, choice of materials and displaying a fragment on a natural scale allows getting the real impression about the harmony of materials, their compatibility and suitability. This part includes the knowledge of students about the materials, their qualities, as well as, in case it is necessary, how and where to find and purchase new appropriate materials, in addition it is closely related to the next item, namely, drafting an estimate.

In addition, drafting an estimate is an integral part of any project to be implemented. Since entrepreneurs plan their budget and allocate a certain amount of money to every activity, students learn to choose the materials in the right way; they learn to adapt to the allocated funding, i. e., to evaluate the artistic and financial aspects.

When planning and managing works, a designer must coordinate the work terms with a commissioner and according to the terms and confirmed sketches, one has to elaborate a plan of works and set the terms. In the final stage of a project the authors usually delegate a part of works to the author of the idea aimed at letting to obtain experience in work planning and collective body management, as well as intensifying the sense of responsibility about the implemented work (see Figure 3,4). 

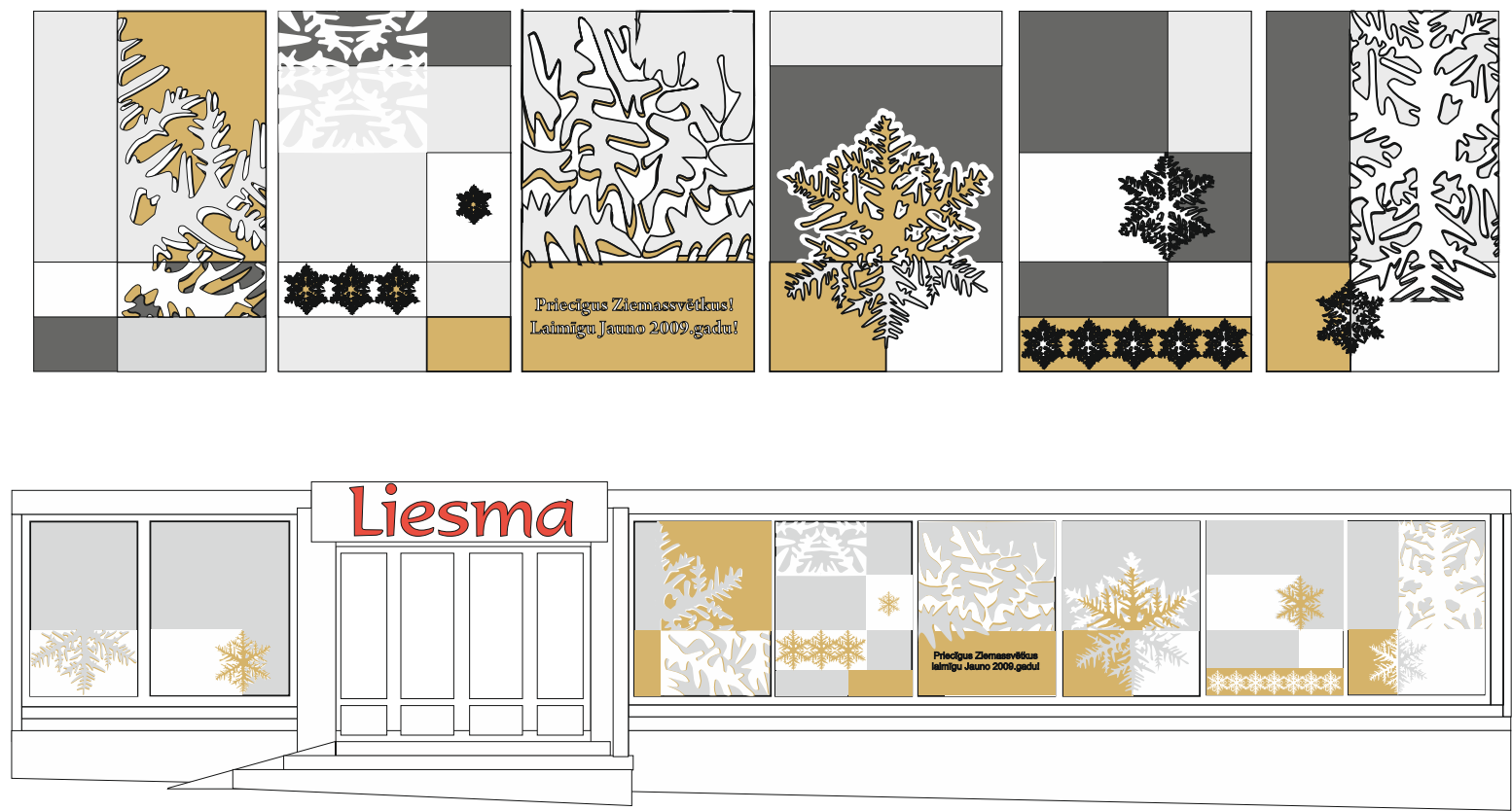

Figure 4. Christmas and New Year window decorations of the stores: Sketches created by the students of study programme on environment design (II)

Considering the wishes of commissioners, during last few years the arrangement of show-windows exposition is not anymore applied in practice, instead the show-window design elements are developed.

Producing and implementing design at a certain object the students participate in plottering, preparation of show-windows for gluing and gluing an adhesive film, what allows carrying out some work in all the stages from the conception till its implementation.

\section{Conclusion}

During the project students improve their skill to create festive design of the town through cooperative learning. The benefit is the experience and participation in creation of festive design of urban environment, as well as appreciation of society. Such creative activities in the town as organization of contests and motivating entrepreneurs to involve in improvement of urban environment, facilitate patriotism, formation of ethic and aesthetic values, participation of society in development of the town.

Besides, the project work is an effective educational method: in the framework of the project "Show-Window Design" the learning environment was diversified and varied, extending its borders and using multiform opportunities. During the work the students obtain experience how to work with customers, they gain confidence in their abilities; it is a real example of work experience for student's CV. In addition, the choice of applicable methods is not the determinative in the cooperative learning, it is more important that students have 


\section{SOCIETY. INTEGRATION. EDUCATION. Volume II}

an opportunity to involve in the planning, evaluation, choice of resources and formation of environment of learning process.

The proportion of learning methods, cooperation with teachers, employers, social partners, representatives of self-governments and non-governmental organisations, ensuring the connection of theory and practice and the intersubject link all develop students' media competence, what expresses in functional use of information, technologies, computer, network, critical and visual competence.

The model for media competence improvement consists of an individual combination of components based on a real situation, precise time planning, theory and practice, intersubject link, resources and students support. It is a tool for successful cooperation of a student and teacher.

\section{References}

Allemann-Ghionda, Cr. (2004). Einführung in die Vergleichende Erziehungswissenscaft. Weinheim und Basel: Belz Studium.

Andrews, R. (2004). The Impact of ICT on Competence Education. New York: RoutledgeFalmer.

Drebes, K. (1993). Gruppenlernen in der Lehrerausbildung - eine Alternative? In: G. L. Huber (Hrsg.), Neue Perspektiven der Kooperation. (S. 118-127). Baltmannsweiler: Schneider Verlag Hohengehren.

Ferrés, J., Piscitelli, A. (2012). Media Competence: An Articulated Proposal of Dimensions and Indicators. In: Comunicar N 38, Scientific Journal of Media Education (pp. 75-82).

Hertz-Lazarowitz, R., Shachar, H. (1990). Teacher verbal behavior in cooperative and wholeclass instruction. In: S. Sharan (Ed.) Cooperative leraning: Theory and research (pp.7794). New York: Preager.

Hippel, A. (2010). Subjective concepts of media competence. In: The University of the Fraser Valley Research Review (pp. 69-80). Vol. 3: issue 2.

Huber, G. L., Rotering-Steinberg, S., Wahl, D. (Eds.) (1984). Kooperatives Lernen. Weinheim: Beltz.

Koena, E. G. (2004). Kooperatīvās mācīšanās ieviešana un organizācija. Krāj.: Kooperatīvā mācīšanās (53-62 lpp.). R.: RaKa.

McClure, C.R. (1994). Network competence: A role for libraries? In: Information technology and libraries (pp. 115-125). No 2, vol. 13.

Plaude, I. (2003). Sociālā pedagogija. R.: RaKa.

Rubene, Z., Krūmiņa A.,Vanaga I. (2008). Ievads mediju pedagogijāa. R.: RaKa.

Šahara, H., Šarans Š. (2004). Skolu darba organizācijas un kooperatîvās mācīšanās savstarpējā sakarība. Krāj.: Kooperatīvā mācīšanās (63-80 lpp.). R.: RaKa.

Tyner, K. (1998). Competence in a Digital World: teaching and learning in the Age of Information. Hillsdale, NJ: Lawrence Erlbaum Associates.

Vygotskij, L. (1978). Mind in Society: The Development of Higher Psychological Processes. Cambridge, Harvard Universiy Press.

Zimmer, G. (2005). Berufliche Bildung und Medien. In: Grundbegriffe Medienpädagogik (S. 30-37). München: Kopaed.

Куриллова, Н. (2005). Медиа-культура. От модерна к постмодерну. Москва: Академический Проект.

Маклюэн, М. (2003). Понимание медиа: внешния расширения человека. Москва: Жуковский: Канон - пресс. 